\title{
Status of the eastern imperial eagle population in Slovakia between 1977 and 2013
}

\author{
Stav populácie orla král'ovského na Slovensku v období 1977-2013
}

\author{
Jozef CHAVKO, Lucia DEUTSCHOVÁ, Štefan DANKO, Jozef MIHÓK, Bedřich LANDSFELD, \\ Jiří PAVELKA, Ladislav ŠNÍRER, Stanislav HARVANČÍK, Andrej DUBRAVSKÝ, \\ Leonidas PREŠINSKÝ \& Richard GALAS̆
}

\begin{abstract}
Between 1977 and 2013 nesting of 72 different pairs of imperial eagle was recorded in Slovakia. The nesting population in Slovakia is concentrated in two subpopulations with the nesting area distant about $200 \mathrm{~km}$. In Eastern Slovakia nesting of 42 pairs was recorded whilst in Western Slovakia 30 pairs were nesting. Authors present results of 37 years period of survey focused on distribution and trend of nesting population, as well as habitat preferences of the species. The paper compares results from Western and Eastern Slovakia. From Western Slovakia further data are evaluated, such as threats negatively influencing the population, period of hatching and other aspects of nesting biology. During the survey period the number of known nesting pairs in Slovakia has increased from five in 1977 to 53 in 2013. In total, 908 nesting events have been recorded during this period with 642 successful nesting events and 1,080 fledglings. In Western Slovakia the pairs prefer foothills, whilst in Eastern Slovakia most of the pairs nest in lowlands. Strong anthropic pressure is significantly influencing the distribution and size of the population as well as the habitat preferences of the species.
\end{abstract}

Abstrakt: V rokoch 1977 až 2013 bolo na Slovensku evidované hniezdenie 72 rôznych párov orla král’ovského. Hniezdna populácia je na Slovensku sústredená v dvoch subpopuláciách vzdialených asi $200 \mathrm{~km}$. Na východnom Slovensku bolo zaznamenané hniezdenie 42 párov, na západnom Slovensku hniezdenie 30 párov. Autori prezentujú výsledky 37-ročného výskumu zameraného na sledovanie rozšírenia a trendu hniezdnej populácie ako aj habitatovej preferencie druhu. V príspevku sa porovnávajú výsledky z východného a západného Slovenska. Zo západného Slovenska sú vyhodnotené aj d’alšie údaje, napríklad hrozby negatívne ovplyvňujúce populáciu, obdobie liahnutia a d’alšie aspekty hniezdnej biológie. Počas sledovaného obdobia sa počet známych hniezdiacich párov na Slovensku zvýšil z piatich v roku 1977 na 53 v roku 2013. V hodnotenom období bolo zaznamenaných 908 hniezdení, 642 hniezdení bolo úspešných, vyletelo celkom 1080 mlád’at. Na západnom Slovensku hniezdne páry preferujú predhoria, zatial’ čo na východnom Slovensku väčšina párov hniezdi v nížinách. Distribúciu, vel'kost' populácie ako aj výber stanovíšt' druhu významne ovplyvňuje silný antropický tlak.

Key words: Aquila heliaca, population trend, conservation

Jozef Chavko, Lucia Deutschová, Štefan Danko, Jozef Mihók, Bedřich Landsfeld, Jiří Pavelka, Ladislav Šnírer, Stanislav Harvančík, Andrej Dubravský, Leonidas Prešinský, Richard Galaš, Raptor Protection of Slovakia, Kuklovská 5, 84104 Bratislava, Slovakia. E-mails of corresponding authors: chavko@dravce.sk, deutschova@dravce.sk, dankostef@gmail.com.

Acknowledgements: We would like to thank to Západoslovenská energetika, a.s., Západoslovenská distribučná, a.s., Východoslovenská energetika, a.s., Východoslovenská distribučná, a.s., Stredoslovenská energetika, a.s., SSE - Distribúcia, a.s., State Nature Conservancy of the Slovak Republic, Ministry of Environment of the Slovak Republic, Dušan Briedik, Gabriel Demeter, David Horal, Márton Horváth, Stanislav Kováč, Ivan Šipkovský, Zdeněk Vermouzek, Alena Zacharová and many others who contributed to conservation of the species.

\section{Introduction}

The overview of historical data on occurrence of the species in Slovakia was described by Danko \& Chavko (1996). The nesting of imperial eagle was recorded in Western and Eastern, no nesting was recorded in Central Slovakia. According to Vili et al. (2009) the western and eastern nesting nuclei can be handled as subpopulations, with slightly limited gene-flow between them.
Implementation of four projects was especially important for the conservation of imperial eagle in Slovakia. The project LIFE03NAT/SK/000098 Conservation of imperial eagle in the Slovak part of the Carpathian basin was implemented under LIFE Programme, with the support of the European Commission. This project was implemented in 2003-2007. Several actions for the conservation of the species have been carried 
out, such as systematic monitoring, designation of protected zones around active nests, use of radio and satellite transmitters, detailed evaluation of data from the transmitters, guarding of nests, repatriation of Spermophilus citellus, ringing of juveniles, care of disabled individuals, colour ringing, DNA analyses, insulation of dangerous $22 \mathrm{kV}$ poles. More information about the project and its results was given by Danko et al. (2011) and Latková et al. (2007).

The project HUSK/1101/2.2.1/0336 Conservation and survey of birds without borders, implemented under Hungary-Slovakia Cross-border Co-operation Programme 2007-2013 is being implemented since 2012 until 2014. This project covers especially systematic monitoring including winter counting of the species in Slovak-Hungarian border region, ringing, solving of bird crime cases, cooperation with Hungarian partners, operation of special database, increasing of public awareness by public relations (PR) activities.

The project N00103 Conservation of raptors and owls Slovakia Austria is being implemented under EUProgram for Cross Border Cooperation SlovakiaAustria 2007-2013, since 2011 until 2014. Under this project systematic monitoring is being carried out in the Slovak-Austrian border region, protected zones around active nests were designated, radio transmitters were used and several cases of bird crime have been solved.

The 7th International Conference on the Conservation of the Eastern Imperial Eagle was organized within a project implemented with a support of International Visegrad Fund.

\section{Methods}

A systematic monitoring of imperial eagle nesting population has been carried out since 1969 in Eastern Slovakia and since 1977 in Western Slovakia. All known nesting territories were under systematic monitoring including historical sites. The monitoring has been carried out especially by ten experts, members of the Raptor Protection of Slovakia (RPS), listed among authors of this article. We estimate that until 1992 approximately $80 \%$ of nesting population was under systematic monitoring and after 1992 it was approximately $90 \%$, comparing the number of pairs under systematic monitoring in known territories with estimated total number of territories (including potential territories). The aim of the monitoring was to determine the real number of nesting pairs, diet and habitat preferences of the species, habitat conditions and other factors influencing the species. Based on this data trend of the population was being evaluated.

\section{Results and discussion}

Between 1977 and 201372 pairs of imperial eagle were nesting 908 times with 642 successful nesting events and 1,080 juveniles (Tab. 1). The trend of population in this period is displayed in Fig. 1.

Fig. 2 shows the area of distribution of nesting population of the species between 1977 and 2013. We assume the distribution was influenced by several factors: presence of suitable feeding and nesting habitats,

Tab. 1. Number of recorded nesting pairs of imperial eagle in Slovakia

Tab. 1. Počet zaznamenaných hniezdnych párov orla král'ovského na Slovensku

\begin{tabular}{|c|c|c|c|}
\hline $\begin{array}{l}\text { year / } \\
\text { rok }\end{array}$ & $\begin{array}{c}\text { all nesting } \\
\text { events / } \\
\text { všetky } \\
\text { hniezdenia }\end{array}$ & $\begin{array}{c}\text { successful } \\
\text { nesting events / } \\
\text { úspešné } \\
\text { hniezdenia }\end{array}$ & $\begin{array}{c}\text { number } \\
\text { of fledglings / } \\
\text { počet } \\
\text { mlád'at }\end{array}$ \\
\hline 1977 & 5 & 3 & 5 \\
\hline 1978 & 7 & 4 & 7 \\
\hline 1979 & 8 & 4 & 6 \\
\hline 1980 & 6 & 2 & 3 \\
\hline 1981 & 8 & 5 & 7 \\
\hline 1982 & 12 & 11 & 12 \\
\hline 1983 & 13 & 5 & 6 \\
\hline 1984 & 13 & 7 & 10 \\
\hline 1985 & 15 & 11 & 14 \\
\hline 1986 & 17 & 12 & 15 \\
\hline 1987 & 14 & 13 & 19 \\
\hline 1988 & 15 & 11 & 18 \\
\hline 1989 & 18 & 11 & 17 \\
\hline 1990 & 19 & 11 & 22 \\
\hline 1991 & 15 & 10 & 16 \\
\hline 1992 & 17 & 12 & 18 \\
\hline 1993 & 20 & 12 & 24 \\
\hline 1994 & 20 & 12 & 20 \\
\hline 1995 & 22 & 15 & 35 \\
\hline 1996 & 22 & 15 & 24 \\
\hline 1997 & 22 & 15 & 25 \\
\hline 1998 & 27 & 22 & 40 \\
\hline 1999 & 29 & 20 & 40 \\
\hline 2000 & 31 & 26 & 53 \\
\hline 2001 & 29 & 25 & 43 \\
\hline 2002 & 32 & 28 & 50 \\
\hline 2003 & 34 & 26 & 46 \\
\hline 2004 & 34 & 26 & 45 \\
\hline 2005 & 39 & 28 & 43 \\
\hline 2006 & 39 & 35 & 64 \\
\hline 2007 & 45 & 33 & 61 \\
\hline 2008 & 40 & 25 & 47 \\
\hline 2009 & 40 & 30 & 51 \\
\hline 2010 & 44 & 23 & 30 \\
\hline 2011 & 39 & 29 & 45 \\
\hline 2012 & 45 & 32 & 49 \\
\hline 2013 & 53 & 33 & 50 \\
\hline $\bar{\Sigma}$ & 908 & 642 & 1,080 \\
\hline
\end{tabular}


disturbance and bird crime in nesting and feeding territories. The northern boundary is given by mountains and nesting territory of golden eagle. The current distribution of nesting population of imperial eagle in Slovakia in 2013 is displayed in Fig. 3 showing significant difference between habitat preferences of nesting subpopulation in Western and Eastern Slovakia. In Western Slovakia majority of pairs are nesting in foothills whilst in Eastern Slovakia majority of pairs are nesting in lowlands. When comparing Fig. 2 and 3, it can be seen that in Western Slovakia the density of nesting pairs comparing to the total area of potential nesting territory is lower than in Eastern Slovakia. The area of potential nesting territory (area of distribution between 1977 and 2013) marked on Fig. 2 is 12,115 $\mathrm{km}^{2}$ in Western Slovakia and $4,671 \mathrm{~km}^{2}$ in Eastern Slovakia. The highest number of nesting pairs recorded between 1977 and 2013 was 20 pairs in year 2007 in Western Slovakia and 37 pairs in year 2013 in Eastern Slovakia. It means the highest density was reached in Western Slovakia in 2007 with 1.7 pairs $/ 1,000 \mathrm{~km}^{2}$ and in Eastern Slovakia in 2013 with 8 pairs $/ 1,000 \mathrm{~km}^{2}$. The difference in density of nesting pairs between both areas has been observed especially after 1990 .

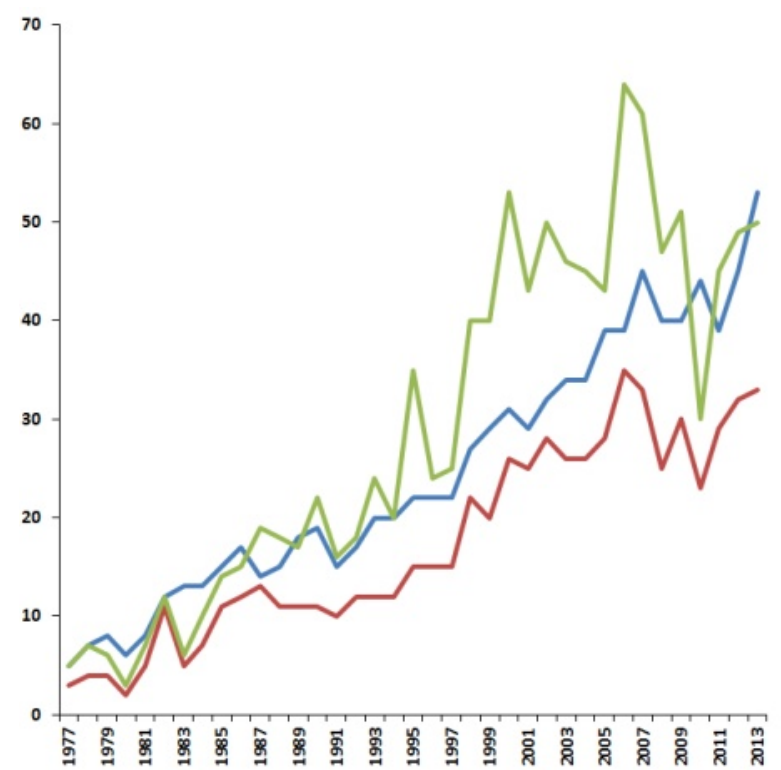

Fig. 1. Trend of imperial eagle population in Slovakia in 1977-2013 (all nesting events - blue line, successful nesting events - red line, number of fledglings - green line; for values see Tab. 1).

Obr. 1. Trend populácie orla král'ovského na Slovensku v rokoch 1977-2013 (všetky hniezdenia - modrá línia, úspešné hniezdenia - červená línia, počet mlád’at - zelená línia; hodnoty sú uvedené v Tab. 1).

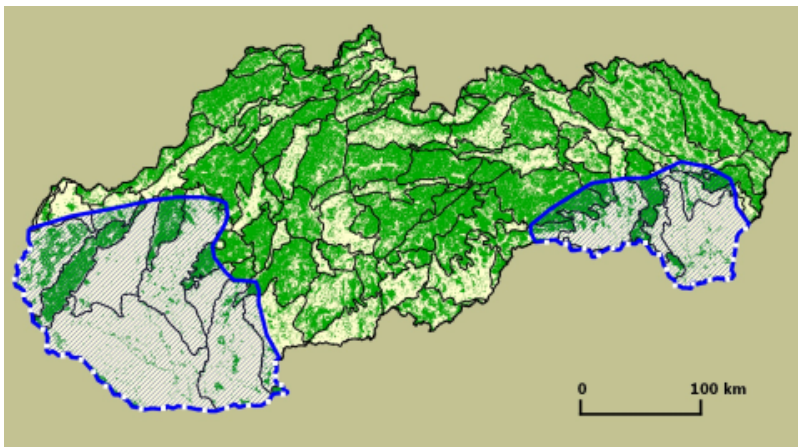

Fig. 2. Range of nesting population of imperial eagle in Slovakia in 1977-2013 (all nesting events in this period).

Obr. 2. Areál hniezdnej populácie orla král'ovského na Slovensku v rokoch 1977-2013 (všetky hniezdenia v období).

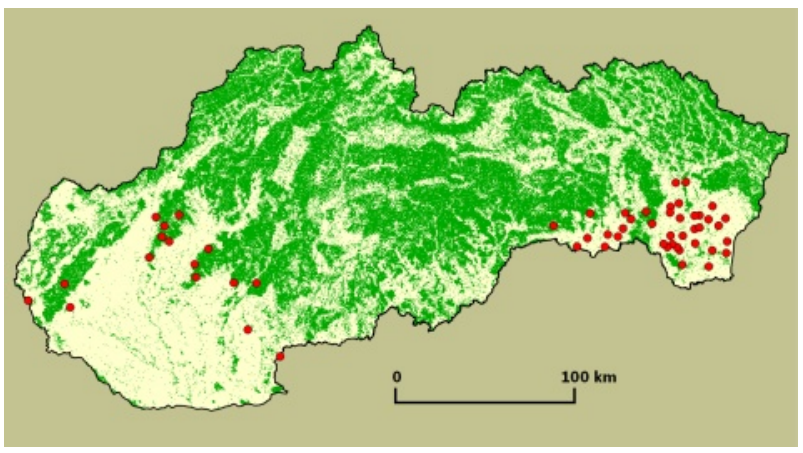

Fig. 3. Distribution of nesting population of imperial eagle in Slovakia in 2013.

Obr. 3. Rozšírenie hnieznej populácie orla královského na Slovensku v roku 2013.

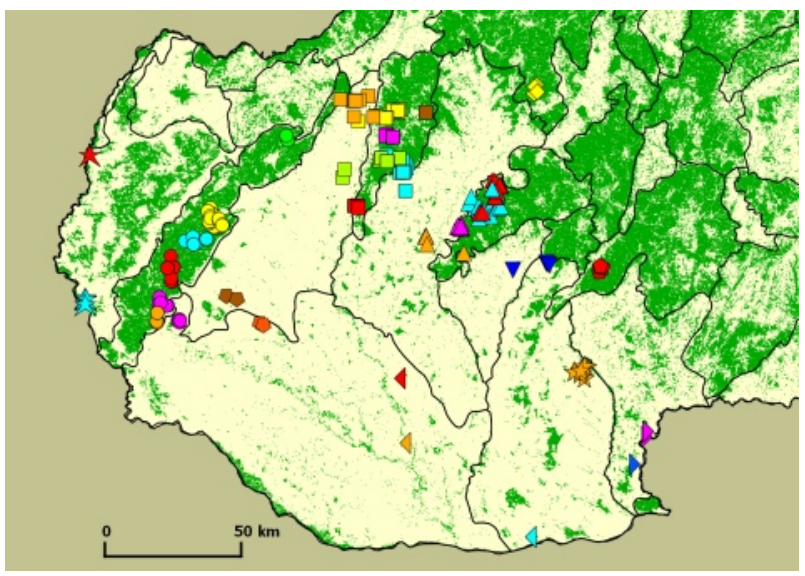

Fig. 4. All nesting events $(n=340)$ of $A$. heliaca pairs recorded in Western Slovakia in 1977-2013 (every pair is marked by different symbol, identical for the whole period of survey).

Obr. 4. Všetky hniezdenia $(n=340) A$. heliaca na západnom Slovensku v rokoch 1977-2013 (každý pár je znázornený rozdielnym symbolom, rovnakým počas celého obdobia výskumu). 
In lowlands of Western Slovakia higher anthropogenic pressure was recorded, especially illegal activities (shooting, poisoning) and intensive urbanization, resulting in lack of suitable nesting and feeding habitats. The above mentioned negative factors can be considered to be a reason of different density of nesting pairs comparing Eastern and Western Slovakia. Other variables, such

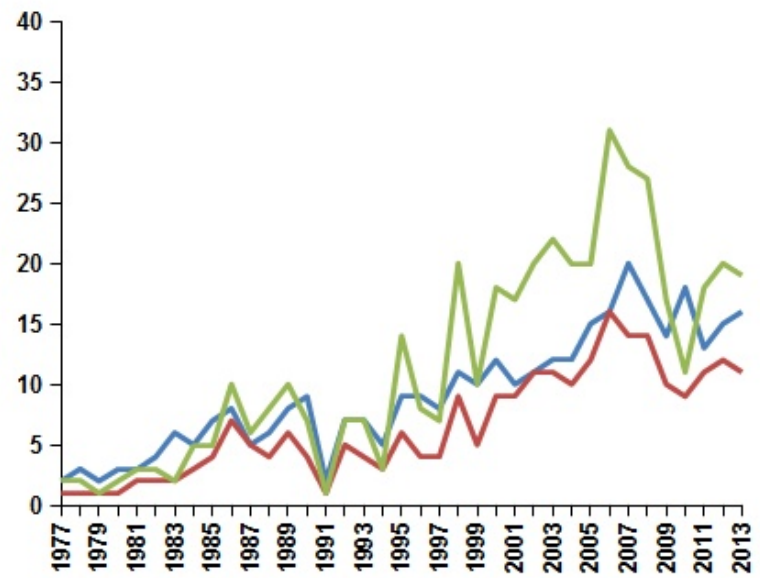

Fig. 5. Trend of subpopulation of $A$. heliaca in Western Slovakia 1977-2013 (all nesting events - blue line, successful nesting events - red line, number of fledglings - green line).

Obr. 5. Trend subpopulácie $A$. heliaca na západnom Slovensku v rokoch 1977-2013 (všetky hniezdenia - modrá línia, úspešné hniezdenia - červená línia, počet mlád’at - zelená línia).

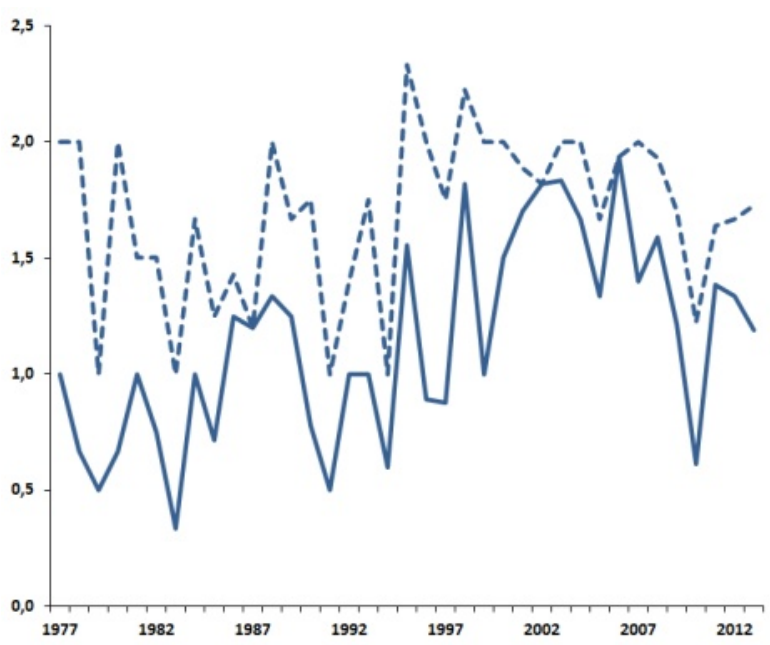

as prey abundance or fluctuation of prey species in between years have not been considered. All nesting events $(n=340)$ of imperial eagle pairs recorded in Western Slovakia in 1977-2013 are displayed in Fig. 4.

Trend of subpopulation in Western Slovakia is shown in Fig. 5. Trend of subpopulation in Eastern Slovakia is shown in Fig. 6. The subpopulation in East-

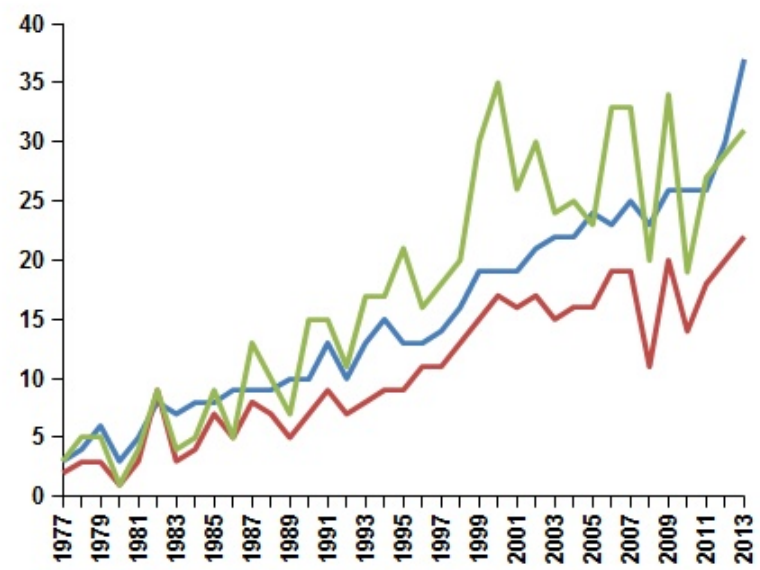

Fig. 6. Trend of subpopulation A. heliaca in Eastern Slovakia 1977-2013 (all nesting events - blue line, successful nesting events - red line, number of fledglings - green line).

Obr. 6. Trend subpopulácie $A$. heliaca na východnom Slovensku v rokoch 1977-2013 (všetky hniezdenia - modrá línia, úspešné hniezdenia - červená línia, počet mlád’at - zelená línia).

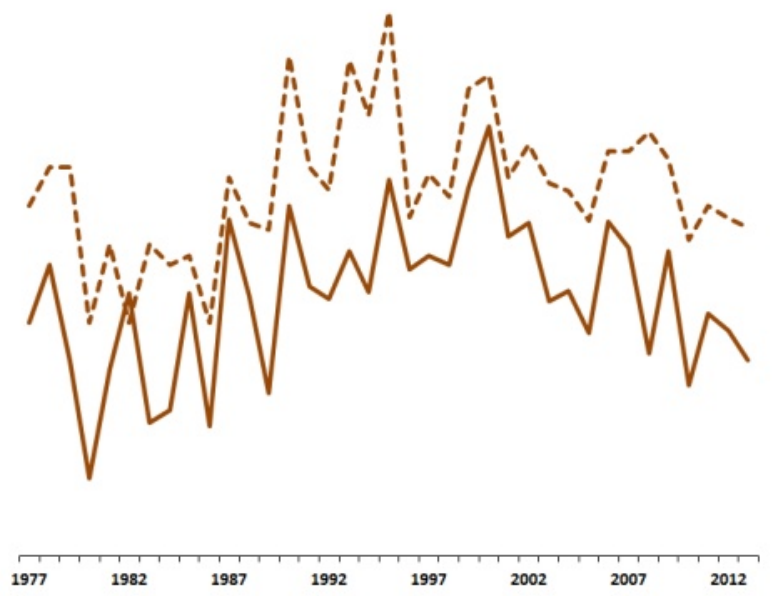

Fig. 7. Comparison of breeding success in Western (blue \& left) and Eastern (brown \& right) Slovakia 1977-2013 (all nesting events - solid lines, successful nesting events - dotted lines).

Obr. 7. Porovnanie hniezdnej úspešnosti na západnom (modrá vlavo) a východnom (hnedá vpravo) Slovensku v rokoch 1977-2013 (všetky hniezdenia - plné čiary, úspešné hniezdenia - prerušované čiary). 
ern Slovakia shows linear growth whilst the subpopulation in Western Slovakia is increasing very slowly. This again can be explained by already mentioned anthrophogenic pressure. Killing of individuals causes the disappearance of pairs from nesting territories. Distur-

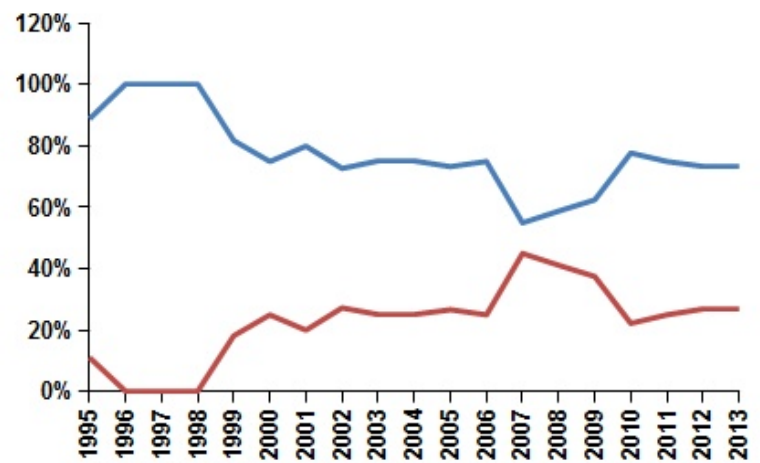

Fig. 8. Habitat preferences of $A$. heliaca subpopulation in Western Slovakia (pairs nesting in foothills - blue line, pairs nesting in lowlands - red line).

Obr. 8. Habitatové preferencie subpopulácie $A$. heliaca na západnom Slovensku (páry hniezdiace $v$ predhoriach - modrá línia, páry hniezdiace v nižinách - červená línia).

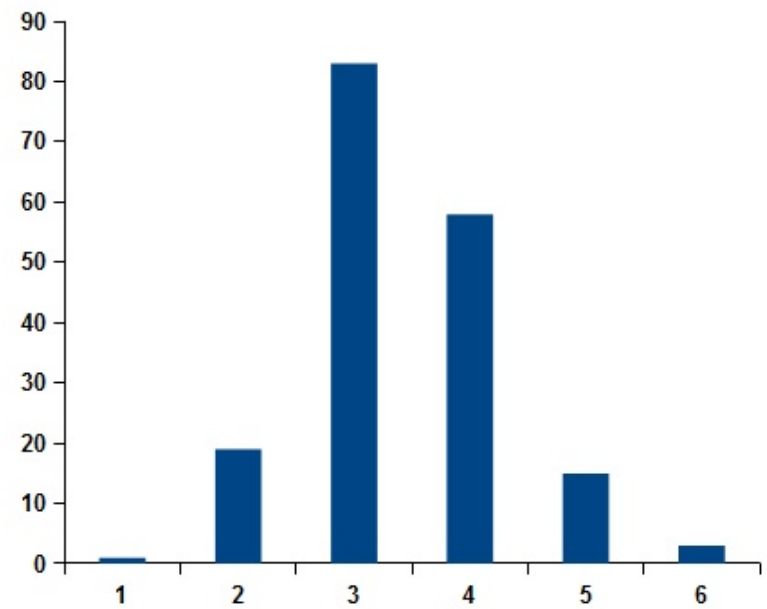

Fig. 10. Estimated date of hatching of $A$. heliaca chicks in Western Slovakia ( $n=179 ; 1$ - April, 2nd decade, 2 - April, 3rd decade, 3 - May, 1st decade, 4 - May, 2nd decade, 5 - May, 3rd decade, 6 - June, 1st decade).

Obr. 10. Odhadovaný dátum liahnutia mlád’at $A$. heliaca na západnom Slovensku $(n=179 ; 1-2$. dekáda apríla, 2 - 3 . dekáda apríla, 3 - 1. dekáda mája, 4 -2. dekáda mája, 5 - 3 . dekáda mája, 6 - 1. dekáda júna). bance by different activities in already occupied or potential breeding and feeding territories reduces the number of suitable nesting habitats. In Fig. 7 breeding success in both parts of the country is compared showing high similarity. This similarity can be explained

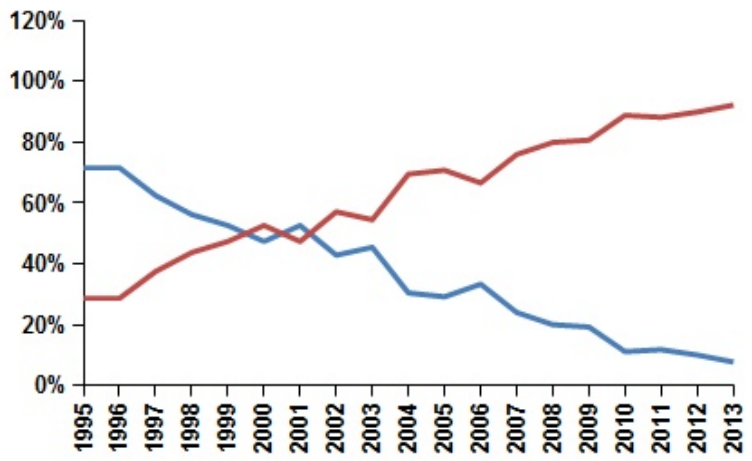

Fig. 9. Habitat preferences of $A$. heliaca subpopulation in Eastern Slovakia (pairs nesting in foothills - blue line, pairs nesting in lowlands - red line).

Obr. 9. Habitatové preferencie subpopulácie $A$. heliaca na východnom Slovensku (páry hniezdiace v predhoriach - modrá línia, páry hniezdiace v nížinách - červená línia).

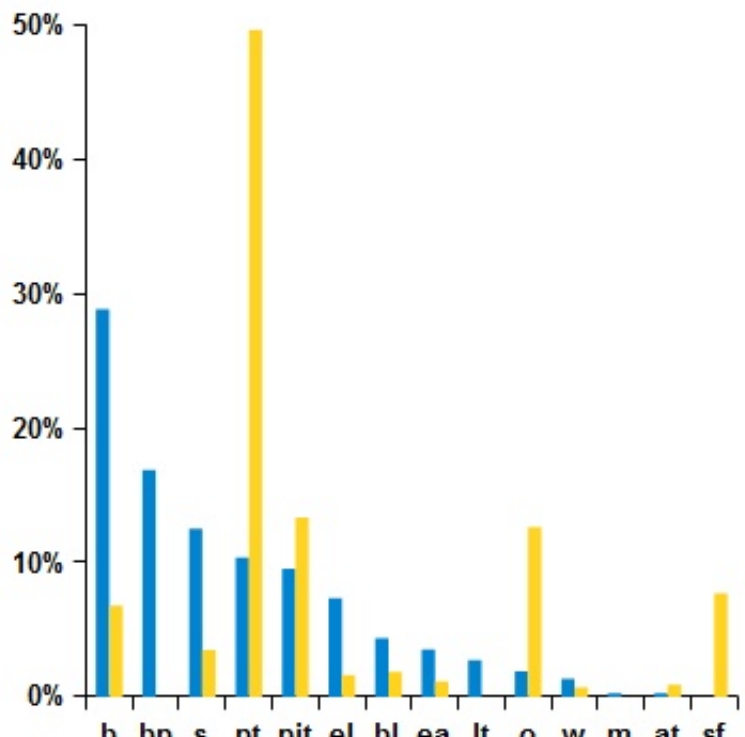

b bp s pt pit el bl ea lt o w m at sf

Fig. 11. Preferences of nesting trees of $A$. heliaca pairs in Slovakia ( $n=794$ nesting events; $b$ - beech, bp - black pine, $\mathrm{s}$ - spruce, pt - poplar tree, pit - pine tree, el - European larch, bl - black locust, ea - European alder, It - lime tree, o - oak, w - willow, m - maple, at - ash tree, sf - silver fir, yellow - Eastern Slovakia, blue - Western Slovakia).

Obr. 11. Preferencia hniezdnych stromov párov $A$. heliaca na Slovensku ( $n=794$ hniezdení; b - buk, bp - borovica čierna, s - smrek, pt - topol', pit - borovica, el - smrekovec, bl - agát, ea - jelša, It - lipa, o - dub, w - vŕba, m - javor, at - jaseň, sf - jedla biela, žltá - východné Slovensko, modrá - západné Slovensko). 


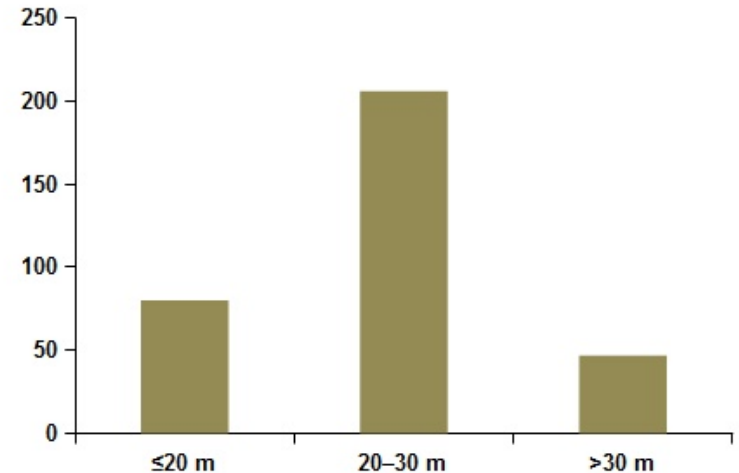

Fig. 12. Preferences of $A$. heliaca pairs concerning location of nests in different heights on the trees ( $n=333$ nesting events). Obr. 12. Preferencie párov $A$. heliaca $z$ hl'adiska umiestnenia hniezda v rôznych výškach na stromoch ( $n=333$ hniezdení).

especially by the dependence of breeding success from the weather conditions. Weather conditions do not generally show a big difference between Eastern and Western part of the country. The preferences of nesting habitat of both subpopulations are shown in Fig. 8 and Fig. 9. In Eastern Slovakia significant decrease in number of pairs nesting in foothills was recorded whilst the number of pairs nesting in lowlands shows significant growth. In Western Slovakia the preferences are changing only slightly.

Data from Western Slovakia about the period of hatching of chicks were evaluated in Fig. 10. These data were estimated from the age of juveniles. Out of 179 cases when the decade was calculated $46 \%$ chicks were hatched in the 1 st decade of May, $32 \%$ in the 2 nd decade of May and $11 \%$ in the 3 rd decade of April.

All of the pairs have only been using nests situated on trees. The preferences of nesting trees were evaluated in Fig. 11, 794 nesting events have been compared (367 from Western Slovakia and 427 from Eastern Slovakia). In Eastern Slovakia the highest preference was given to poplar tree (Populus sp.) with 49.6\%. In Western Slovakia the beech tree (Fagus sylvatica) was preferred with $28.9 \%$. The poplar tree is one of the most typical tree species in lowlands and the beech tree in foothills. Estimated height of the nest was compared in case of 333 nesting events of both subpopulations (Fig. 12).

Illegal activities strongly influence the distribution and size of the imperial eagle subpopulation in Western Slovakia - 18 cases of illegal killing of imperial eagle individuals have been recorded between 2003 and 2013

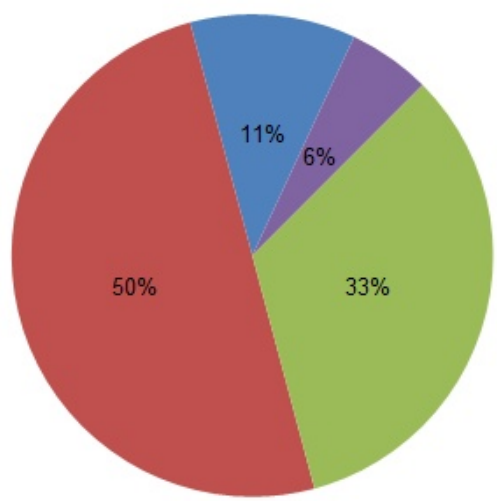

Fig. 13. Cases of illegal killing of imperial eagle individuals in Slovakia in 2003-2013 $(n=18$; nest robbery, 2 cases - blue, poisoning, mostly carbofuran, 9 cases - red, shooting of individuals or nests, 6 cases - green, unknown, 1 case - violet). Obr. 13. Prípady ilegálneho usmrtenia orlov král'ovských na Slovensku v období 2003-2013 (n=18; vykradnutie hniezd, 2 prípady - modrá, otravy, prevažne karbofuran, 9 prípadov - červená, zástrely jedincov alebo vystrel'ovanie hniezd, 6 prípadov - zelená, neznáme, 1 prípad - fialová).

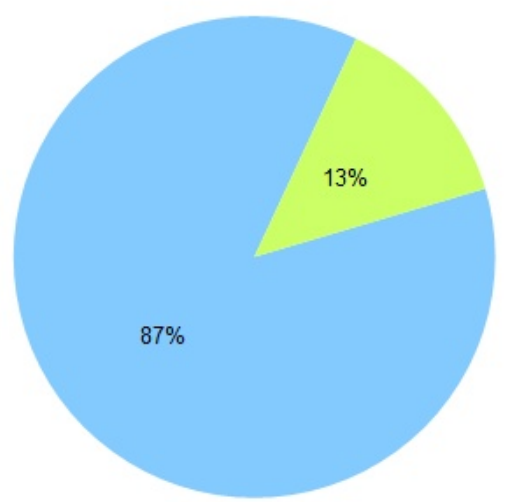

Fig. 14. All bird crime cases (all bird species) in Slovakia in 1979-2013 ( $n=245$; poachers, hunters, falconers, poisoning, shooting, traps, illegal breeding, 212 cases - blue; other, 33 cases - green).

Obr. 14. Všetky prípady vtáčej kriminality (všetky druhy vtákov) na Slovensku v období 1979-2013 ( $n=245$; pytliaci, pol'ovníci, sokoliari, otravy, strel'ba, pasce, nelegálny chov, 212 prípadov modrá; d’alšie, 33 prípadov - zelená).

(Fig. 13). In Eastern Slovakia only two cases of disturbance have been recorded in this period. Between 1979 and 2013245 cases of bird crime (all bird species) was recorded in total in the whole territory of Slovakia (Fig. 14). It is necessary to underline the fact that only confirmed cases have been recorded in the database however the number of all cases is considerably higher. If we include poisoning, shooting, poaching and illegal 
nesting in one group, this group represents $87 \%$ of all recorded illegal cases. These results demonstrate a high threat for the imperial eagle population. In Western Slovakia the bird crime can be considered for the most important threat especially after 2003.

Among other threats the electrocution should be mentioned. This threat is being solved in the whole territory of Slovakia by insulation of the dangerous $22 \mathrm{kV}$ electric poles by the responsible electric companies.

According to Demerdzhiev et al. (2011) the quality of monitoring is determining the level of knowledge about the species, including data about population size, distribution, trends etc. The improvement in the quality of surveys is well reflected by the number of known nesting pairs of the eastern imperial eagle in Europe, which increased by one order of magnitude from 154 in 2000 (Horváth et al. 2002) to 1,134 by 2010 (Demerdzhiev et al. 2011). The same methodology of systematic monitoring of the species in Slovakia is being carried out since 1992. The population in Slovakia has increased from 17 pairs in 1992 to 53 pairs in 2013. It means the population has increased more than three-fold in 21 years. Subpopulation of Western Slovakia has increased by 14 pairs whilst the subpopulation of Eastern Slovakia by 34 pairs. The reason of this trend is likely to be the already mentioned strong anthropic pressure in western part of the country. In 2010 the population of imperial eagle in Slovakia was 44 nesting pairs, representing $25 \%$ of Central European population (Demerdzhiev et al. 2011). Nesting population of imperial eagle in Slovakia is of a high importance for the stability of whole European population of the species. It is thus necessary to continue conservation measures in the country with special attention to prevention, detecting and solving of bird crime cases, especially in Western Slovakia. To follow this goal cooperation on international level is especially important.

\section{References}

Danko Š \& Chavko J 1996: Breeding of the imperial eagle (Aquila heliaca) in Slovakia, 415-423. In: Meyburg B-U \& Chancellor RD (eds): Eagle Studies. World Working Group on Birds of Prey (WWGBP), Berlin, London \& Paris, 549.

Danko S̆, Chavko J, Demeter G, Mihók J, Izakovič J, Latková H, Siryová S, Noga M \& Nemček V 2011: Conservation of eastern imperial eagle in the Slovak part of the Carpathian basin - Results of the EU LIFE-Nature project (2003-2007). Acta zoologica Bulgarica Supplementum 3: 71-78.

Demerdzhiev D, Horváth M, Kovács A, Stoychev S \& Karyakin I 2011: Status and population trend of the eastern imperial eagle (Aquila heliaca) in Europe in the period 2000-2010. Acta zoologica Bulgarica Supplementum 3: 5-14.

Horváth M, Haraszthy L, Bagyura J \& Kovács A 2002: Eastern imperial eagle (Aquila heliaca) populations in Europe. Aquila 107-108: 193-204.

Latková H, Siryová S \& Noga M 2007: Conservation of the imperial eagle in the Slovak part of the Carpathian basin 2003-2007 - Layman's report LIFE03 NAT/SK/000098. Raptor Protection of Slovakia, Bratislava, 16.

Vili N, Chavko J, Szabó K, Kovács S, Hornung E, Kalmár L \& Horváth M 2009: Genetic structure of the imperial eagle (Aquila heliaca) population in Slovakia. Slovak Raptor Journal 3: 21-28. DOI: 10.2478/v10262-012-0029-z. 